\title{
Factors Affecting Consumer- Based Brand Equity from the Perspective of Turkish Consumers
}

\section{Čimbenici koji utječu na tržišnu vrijednost proizvoda iz perspektive turskih potrošača}

\author{
Original scientific paper • Izvorni znanstveni rad \\ Received-prispjelo: 28. 3. 2018. \\ Accepted-prihvaćeno: 5. 3. 2019. \\ UDK: $630 * 75 ; 630 * 836.1$ \\ https://doi.org/10.5552/drvind.2019.1812
}

\begin{abstract}
This paper contributes to the consumer-based brand equity literature by researching what brand equity means for Turkish consumers and by defining factors that, from their perspective, affect Consumer-Based Brand Equity (CBBE). According to our literature review, although some important cross-cultural studies about $C B B E$ can be found, some aspects of this topic require further research. The target population of the study is households in the Western Black Sea Region. This region was chosen because it is a manageable size, geographically close to the researchers, and statistically representative of the Turkish people. Turkish panel furniture (PF) brands were chosen as the sample, and a stratified sampling method was used to determine the questionnaires sample size. Data were analysed in SPSS, incorporating statistical tests such as factor analysis, correlation analysis and chi-square tests. Factors that affected CBBE were marketing activities, perceived quality, brand awareness, brand association and price.
\end{abstract}

Keywords: consumer-based brand equity, Turkey, consumer behaviour, panel products, furniture

SAŽETAK • Zahvaljujući provedenom istraživanju značenja vrijednosti robne marke za potrošače u Turskoj, ovaj rad pridonosi obogaćivanju literature o tržišnoj vrijednosti robne marke. Uzimajući u obzir perspektivu potrošača u Turskoj, definirani su čimbenici koji utječu na tržišnu vrijednost robne marke (CBBE). Iz pregleda literature može se vidjeti da još postoje određeni aspekti područja tržišne vrijednosti robne marke koje treba dodatno istražiti premda su objavljene neke važne studije s tog područja. Ciljna populacija u ovom istraživanju bila su kućanstva u Zapadnoj crnomorskoj regiji, koja je odabrana jer je odgovarajuće veličine, zemljopisno je bliska istraživačima i statistički je reprezentativna za populaciju Turske. Za uzorke su odabrani proizvodi turskoga pločastog namještaja (PF), a za određivanje veličine uzorka primijenjena je metoda stratificiranog uzorkovanja. Podatci su analizirani u SPSS-u upotrebom statističkih testova kao što su faktorska analiza, korelacijska analiza $i$ $\chi^{2}$-testovi. Čimbenici koji su utjecali na tržišnu vrijednost robne marke bili su marketinške aktivnosti, percipirana kvaliteta, prepoznatljivost marke, udruživanje robnih marki i cijena.

Ključne riječi: tržišna vrijednost robne marke, Turska, ponašanje potrošača, pločasti materijali, namještaj

\footnotetext{
${ }^{1}$ Author is researcher at Karadeniz Technical University, Faculty of Forestry, Department of Forest Industry Engineering, Trabzokyn, Turkey, ${ }^{2}$ Author is researcher at Kastamonu University, Faculty of Forestry, Department of Forest Industry Engineering, Kastamonu, Turkey. ${ }^{3}$ Author is researcher at Artvin Çoruh University, Artvin Vocational School, Department of Forestry and Forest Production, Artvin, Turkey.

Autor je istraživač Tehničkog sveučilišta Karadeniz, Šumarski fakultet, Zavod za inženjerstvo u šumarstvu, Trabzokyn, Turska. ${ }^{2}$ Autor je istraživač Sveučilišta u Kastamonu, Šumarski fakultet, Zavod za inženjerstvo u šumarstvu, Kastamonu, Turska. ${ }^{3}$ Autor je istraživač Sveučilišta Artvin Çoruh, Strukovna škola Artvin, Zavod za šumarstvo i proizvodnju, Artvin, Turska.
} 


\section{INTRODUCTION}

\section{UVOD}

Because of its importance for building brand loyalty and awareness, many academics and practitioners have been showing interest for the concept of brand equity for a long time (Erdem et al., 1999). It has been an important marketing concept since the 1980s (Keller, 1998). Today, the literature has different definitions of brand equity, which can be approached from the perspective of an investor, manufacturer, retailer, or consumer (Cobb-Walgren et al., 1995). Aaker (1991) defined brand equity as a set of assets and liabilities linked to a brand's name and symbol, which add to or subtract from its intrinsic value. Keller (1993) defined brand equity as the effect that brand knowledge has on a consumer's response to that brand's marketing efforts. McQueen (1991) defined brand equity as the difference between the value of a branded product versus a non-branded one.

All these definitions agree that a brand's value correlates directly with its effect on consumers. Consequently, if a brand has no value to a consumer, it has little value to investors, manufacturers, and retailers (Farquhar, 1989; Crimmins, 1992).

In the literature, brand equity has been examined from a financial and a consumer-based perspective (Lassar et al., 1995). When anonymous financial data are used to measure brand equity, it is defined as financially based brand equity. In contrast, when individual consumer surveys are performed, this is consumerbased brand equity (CBBE) (Koçak et al., 2007). This paper emphasises the latter perspective in favour of the former, for two reasons. First, CBBE provides financial gains to firms. Secondly, managers have no consumer-based instrument to measure brand equity (Lassar et al., 1995).

Recent studies such as Colicev et al. (2018); Swimberghe et al. (2018); Datta et al. (2017); Girard et al. (2017) prove that the concept of consumer-based brand equity (CBBE) has grown in importance. The literature conceptualises CBBE in several ways (Netemeyer et al., 2004). For instance, Yoo and Donthu, leading researchers on brand equity, described the CBBE as consumers' different responses to a focal brand and an unbranded product, when both have the same level of marketing stimuli and product attributes (Yoo and Donthu, 2001).

True consensus about the definition of $\mathrm{CBBE}$ is elusive. Several alternative methods have been offered for measuring brand equity. Despite the large number of suggested alternatives, no single measure is ideal (Cobb-Walgren et al., 1995). Various brand equity measurement methods have been suggested, based on a consumer's perspective and marketing, but their use is limited (Pappu et al., 2005).

This paper adopted the multidimensional scale of Yoo and Donthu. According to the literature, this scale is widely used in this kind of studies and is also the most robust brand equity scale (Baalbaki and Guzmán, 2016). In addition, Yoo and Donthu claim that their scale is reliable, valid, and useable across several cultures and product categories (Yoo and Donthu, 2001). However, as already mentioned above, there are still disagreements about a globally accepted measurement instrument (Ioannou and Rusu, 2012).

Our literature review shows that cross-cultural tests of scales may be different. For instance, in 2007, using the exact same scale developed and tested in Spain, Koçak and friends tried to replicate the results of Vazquez et al. (2002) in Turkey. They found that the scale did not work well in Turkey and that it had to be modified, concluding that the reason behind this difference was cultural differences (Koçak et al., 2007). Overall, cross-cultural research on brand equity has been insufficient (Ioannou and Rusu, 2012).

The aim of this research is to fill an important gap in the literature by using a widely adopted scale, examining its validity in a different culture and industry, and determining factors affecting CBBE.

\section{MATERIALS AND METHODS}

\section{MATERIJALI I METODE}

Households in seven city centres on the Western Black Sea were the target population of this study. Comprehensive, recent and reliable data about the population and housing from a census conducted by Turkstat in 2011 were used. It was determined that an examination of just provincial centres sufficed. Therefore, we limited our research in the region to only seven provinces, specifically: Bartın, Sinop, Karabük, Bolu, Düzce, Kastamonu, and Zonguldak. The study covers the period from 2015-2017.

The questionnaire directly focused on consumers. Like most related research, we used Aaker and Keller's CBBE approach. As noted earlier, we chose Yoo and Donthu's (2001) multidimensional brand equity scale, and we modified it based on industry investigations and opinions of expert academics. Their scale subdivides brand equity into different subcategories, such as brand awareness, brand associations, perceived quality and brand loyalty. It was chosen because Yoo and Donthu were the first to develop a multidimensional CBBE scale to test its psychometric properties (Pappu et al., 2005). Since our goal was to test the Turkish consumer behaviour, brand reaction and brand equity, the scale fitted our purposes.

The questionnaire uses 5-point Likert scale type questions, open-ended questions, and dichotomous questions. The questionnaire contains 47 items for testing the CBBE. The items are: "The price of the brand is high", "The price of the brand is low", "The brand deserves the price", "The brand is constantly reminded to the consumers", "The ad campaigns for the brand seem very expensive, compared to campaigns for competing brands", "The ad campaigns for the brand are seen frequently", "Price deals for the brand are frequently offered", "Discounts for the brand are made many times.", "Price deals for the brand are shown to be more advantageous than they actually are.", "The 
products are sold in high quality products selling stores.", "The products are sold in luxury stores.", "The products are sold in stores that sell well known brands", "More stores sell the brand, as compared to its competing brands.", "The brand has more dealers, as compared to its competing brands.", "The brand is distributed through as many stores as possible", "The brand is of high quality", "The likely quality of the brand is extremely high", "The likelihood that the brand's new products would be functional is very high", "The brand has an experienced and long-established history.", "The brand uses high technology", "The products deserve their prices", "I trust the brand as a company very much.", "The brand's products must be of very high quality.", "The brand's products seem to be of very poor quality", "I feel faithful to the brand.", "The brand is my first choice in shopping", "If the brand is in the store, I don't buy other brands.", "I am aware of the brand", "I can recognise the brand among other competing brands", "I have enough knowledge of the brand", "Some characteristics of the brand come to my mind quickly", "I can easily remember the brand's logo or symbol", "I have difficulty in imagining the brand in my mind", "The brand has an international reputation", "The brand has effective ads", "The slogans of the brand are catchy", "The brand is a top selling brand", "The product variety of the brand is a lot", "Even if another brand is exactly the same, I would prefer to buy the brand", "Even if another brand has the same features as the brand, I would prefer to buy the brand", "Even if another brand is as good as the brand, I would prefer to buy the brand", "Even if another brand is as good as the brand and more economical, I would prefer to buy the brand", “ Since the brand will make me more satisfied with the after sales technical support than the competitors, I would prefer to buy the brand", "It makes sense to buy the brand instead of any other brand, even if they are the same", "It is preferable because of being a domestic brand", "It is preferable because of being a foreign brand" and "It is important for me that the brand contributes to social projects".

Data were collected by using web-based surveys and face-to-face interviews. Google forms were used for web-based surveys. The e-mail addresses of the people living in the target cities were collected via social media and from various governmental organisations' web-sites such as universities, hospitals, etc. The surveys could only be answered by one person in each household. IP-based restrictions prevented multiple answers from the same household.

Initially, the sample size was calculated and then the questionnaires were given to the target population. Then the data were analysed and interpreted by using appropriate statistical methods. From the perspective of Turkish consumers, this identified the important factors about $\mathrm{CBBE}$.

The following equation (1) was used (Daniel, 1999):

Where:

$$
n=\frac{Z^{2} \cdot N \cdot P \cdot Q}{N \cdot D^{2}+Z^{2} \cdot P \cdot Q}
$$

$n-$ is the required sample size

$N-$ is the population size

$Z$ - is the confidence level (typical levels of confidence for surveys are $95 \%$, in which case $Z$ is set to 1.96.)

$P$ and $Q-$ are the population proportions (they are both set to 0.5 )

$D$ - is the accuracy of sample proportions (set to $5 \%$ ).

Therefore, the sample size was calculated as (2):

$$
n=\frac{1.96^{2} \cdot 629000 \cdot 0.5 \cdot 0.5}{629000 \cdot 0.05^{2}+1.96^{2} \cdot 0.5 \cdot 0.5}=384
$$

The intention was to cover all the provinces, but because household amounts were not homogeneous, stratified sampling was applied. This sampling method is preferred when the sample is not homogeneous, because it can affect the dependent variable (Can, 2014).

Basic statistics for all the provinces are given in Table 1 below.

Based on the data in Table 1, the percentage distribution of questionnaires, by provinces, is shown in the following graph.

The following methods were used for statistical evaluation.

Table 1 Samples

Tablica 1. Uzorci

\begin{tabular}{|l|c|c|c|}
\hline \multicolumn{1}{|c|}{$\begin{array}{c}\text { Province } \\
\text { Pokrajina }\end{array}$} & $\begin{array}{c}\text { Number of households } \\
\text { (thousand) } \\
\text { Broj kućanstava } \\
\text { (u tisućama) }\end{array}$ & $\begin{array}{c}\text { Number of questionnaires required } \\
\text { (according to stratified sampling) } \\
\text { Broj potrebnih anketa } \\
\text { (prema stratificiranom uzorkovanju) }\end{array}$ & $\begin{array}{c}\text { Number of answered } \\
\text { questionnaires } \\
\text { Broj ispunjenih } \\
\text { anketa }\end{array}$ \\
\hline Bartın & 53 & 32 & 42 \\
\hline Sinop & 63 & 38 & 57 \\
\hline Karabük & 66 & 40 & 65 \\
\hline Bolu & 79 & 48 & 49 \\
\hline Düzce & 90 & 55 & 95 \\
\hline Kastamonu & 105 & 64 & 122 \\
\hline Zonguldak & 173 & 106 & 491 \\
\hline $\begin{array}{l}\text { West Black Sea } \\
\text { Zapadna crnomorska regija } \\
\text { (Total / ukupno) }\end{array}$ & 629 & 384 & \\
\hline
\end{tabular}




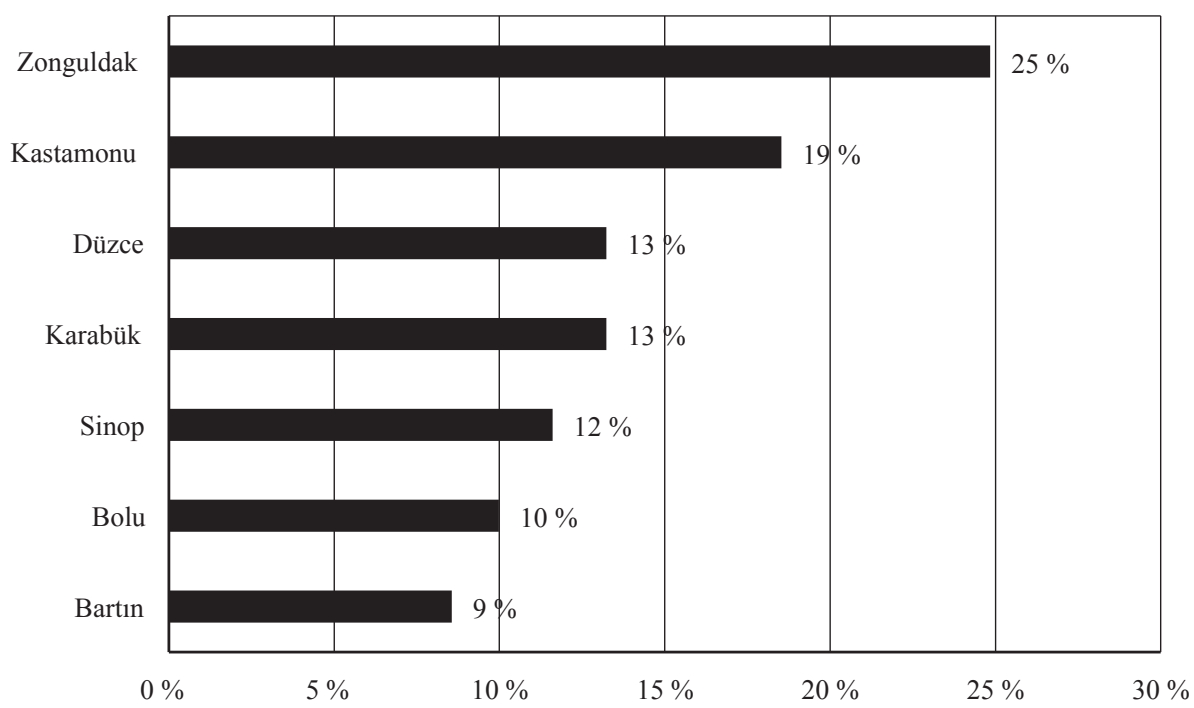

Figure 1 Percentage distribution of questionnaires, by province

Slika 1. Postotna raspodjela anketa prema pokrajinama

\section{Reliability Analysis}

Reliability analysis assesses the reliability of questionnaires, tests, or scales used for measurement (Kalayci, 2009). Cronbach's alpha coefficient was used in this study.

According to an analysis by IBM SPSS Statistics (the programme used for all statistical tests in this study), the scale's reliability coefficient $(\alpha)$ was calculated as 0.9005 , which means that it is extremely reliable.

\section{Factor Analysis}

Factor analysis is a multivariate statistical method that creates fewer unrelated and conceptually significant new variables (factors or dimensions) by combining interrelated variables ('p units') (Büyüköztürk, 2014).

Factor analysis is a statistical method that aims to explain measurement by collecting variables of the same structure or quality.

In this study, factor analysis was used to express the 47 items in the questionnaire more clearly, and to reduce the number of existing items. For the factor analysis, in the beginning, the number of factors to be retained needs to be decided. Therefore, the SPSS default rule was used, which cuts off the factor eigenvalues less than 1 . Then the items that had less than $50 \%$ of communality variance were removed and the factor analysis was repeated. The number of factors was calculated as 5. Afterwards, the analysis was repeated again for the last time. As suggested by Hair et al. (2014), as the sample size was over 350 , the cut-off point was accepted as 0.30 , and then the overlapping items in the factors were removed and the final result was obtained.

\section{Correlation Analysis}

Correlation analysis is a statistical method used to evaluate either the existence of a linear relationship between two variables or the strength and direction of the relationship between one or more variables (Kalayc1, 2009; Büyüköztürk, 2014). Correlation analysis was done according to outcomes of factor analysis.

\section{Chi-Square Test}

The chi-square test consists of three different types of analysis: goodness of fit, a test of independence and a test for homogeneity, all of which are useful for this study (Kalayc1, 2009).

A chi-square analysis was used to examine if there was any statistical relationship between consumers' favourite panel furniture brand and their demographics.

\section{RESULTS AND DISCUSSION} 3. REZULTATI I RASPRAVA

The total number of analysed questionnaires is 491. Respondents' genders were balanced, $53.2 \%$ (261) male and $46.8 \%$ (230) female. $50.3 \%$ (247) of respondents were under 30 years old and $49.7 \%$ (244) were between 30 and 60 years of age. The study's cutoff age was 61.

Questionnaires used a stratified sampling method. For this reason, the largest number of questionnaires (122) was distributed in Zonguldak, the provincial centre, which has the highest number of households. The lowest number of questionnaires (42) was distributed in Bartın, also a provincial centre, which has the smallest number of households in the Western Black Sea region. The Zonguldak surveys constituted $24.8 \%$ of the total, while those from Bartın constituted $8.6 \%$.

Culling the respondents by different categories yielded the following results:

$-52.3 \%$ (257) of the respondents were single, and $47.7 \%$ (234) were married.

$-41.5 \%$ (204) were university graduates, $28.8 \%$ (141) were postgraduates, $23 \%$ (113) were high school graduates, $3.7 \%$ (18) were middle school graduates and $3.1 \%(15)$ were primary school graduates.

$-69.8 \%$ (343) were working, $26.1 \%$ (128) did not work, and $4.1 \%$ (20) were retired.

$-26.1 \%$ (128) earned less than 1000TL (167 €) per month, $17.3 \%$ (85) earned 1000-1999TL (167-333 


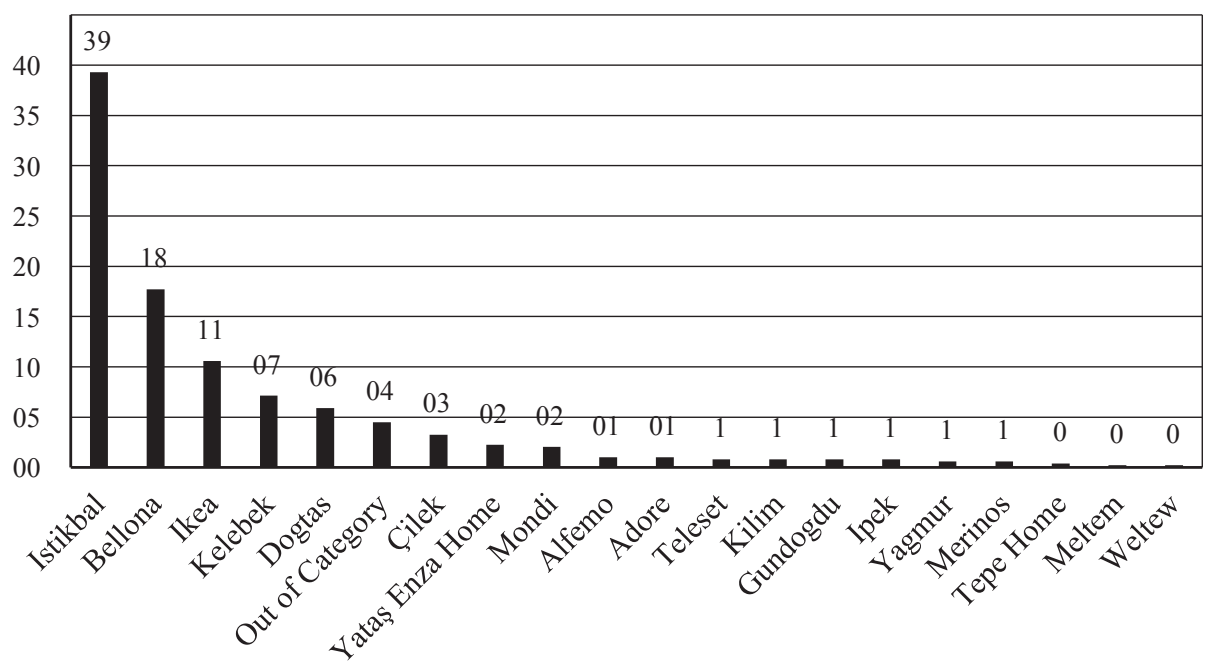

Figure 2 Panel furniture consumer recollection rate (\%)

Slika 2. Stupanj prisjećanja potrošača pločastog namještaja (\%)

$€)$ per month, $20.8 \%$ (102) earned 2000-2999TL (334-500 €) per month, $22.26 \%$ (111) earned 30003999TL (501-666 €) per month, and $13.2 \%(65)$ earned 4000TL (667 $€$ ) or more per month. The currency conversions were made as of December 2018.

Participants were randomly selected, and approximately $71 \%$ (350 responses) of the questionnaires were answered face-to-face. The remaining 141 questionnaires (approximately $29 \%$ ) were answered via the Internet.

When the respondents were asked about the remembered panel furniture brands, the results were as follows: İstikbal was remembered by 193 people, Bellona by 87 people, Ikea by 52 people, Kelebek by 35 people, Doğtaş by 29 people, Yağmur and Merinos by 3 people, Tepe Home by 2 people, and Meltem and Weltew by 1 person. In the questionnaire, only 24 large panel furniture manufacturers were examined. A more detailed explanation can be seen in Figure 2.

In Table 2 below, consumers were asked why they preferred certain brands, i.e. what were their priorities for purchasing a branded product. The most important reason as the first priority $(26.3 \%)$ for choosing a brand is the experience with the brand, meaning that the customers have used the brand before. The most important reason as the second priority $(23.0 \%)$ is distribution: customers can find products easily. The most important reason as the third priority $(22.0 \%)$ is

Table 2 Reasons to buy preferred brands

Tablica 2. Razlozi za kupnju željene robne marke

\begin{tabular}{|c|c|c|c|c|c|c|c|c|}
\hline \multicolumn{3}{|c|}{$\begin{array}{c}\text { 1st Priority } \\
\text { 1. izbor }\end{array}$} & \multicolumn{3}{|c|}{$\begin{array}{l}\text { 2nd Priority } \\
\text { 2. izbor }\end{array}$} & \multicolumn{3}{|c|}{$\begin{array}{l}\text { 3rd Priority } \\
\text { 3. izbor }\end{array}$} \\
\hline $\begin{array}{l}\text { Reason } \\
\text { Razlog }\end{array}$ & $N$ & $\begin{array}{l}\text { Percentage } \\
\text { Postotak }\end{array}$ & $\begin{array}{l}\text { Reason } \\
\text { Razlog }\end{array}$ & $N$ & $\begin{array}{l}\text { Percentage } \\
\text { Postotak }\end{array}$ & $\begin{array}{l}\text { Reason } \\
\text { Razlog }\end{array}$ & $N$ & $\begin{array}{c}\text { Percentage } \\
\text { Postotak }\end{array}$ \\
\hline $\begin{array}{l}\text { For being used at } \\
\text { home } \\
\text { namijenjena je } \\
\text { uporabi kod kuće }\end{array}$ & 129 & 26.3 & $\begin{array}{l}\text { Products can be } \\
\text { found everywhere } \\
\text { može se pronaći } \\
\text { bilo gdje }\end{array}$ & 113 & 23 & $\begin{array}{l}\text { For being a trusted } \\
\text { brand } \\
\text { to je marka kojoj } \\
\text { vjerujem }\end{array}$ & 108 & 22 \\
\hline $\begin{array}{l}\text { For being the best } \\
\text { quality brand } \\
\text { to je marka } \\
\text { najbolje kvalitete }\end{array}$ & 126 & 25.7 & $\begin{array}{l}\text { For being the } \\
\text { best-quality brand } \\
\text { to je marka } \\
\text { najbolje kvalitete }\end{array}$ & 112 & 22.8 & $\begin{array}{l}\text { Products can be } \\
\text { found everywhere } \\
\text { može se pronaći } \\
\text { bilo gdje }\end{array}$ & 100 & 20.4 \\
\hline $\begin{array}{l}\text { For being a trusted } \\
\text { brand } \\
\text { to je marka kojoj } \\
\text { vjerujem }\end{array}$ & 118 & 24 & $\begin{array}{l}\text { For being a trusted } \\
\text { brand } \\
\text { to je marka kojoj } \\
\text { vjerujem }\end{array}$ & 109 & 22.2 & $\begin{array}{l}\text { For being used at } \\
\text { home } \\
\text { to je marka kojoj } \\
\text { vjerujem }\end{array}$ & 80 & 16.3 \\
\hline $\begin{array}{l}\text { Products can be } \\
\text { found everywhere } \\
\text { može se pronaći } \\
\text { bilo gdje }\end{array}$ & 62 & 12.6 & $\begin{array}{l}\text { For being used at } \\
\text { home } \\
\text { namijenjena je } \\
\text { uporabi kod kuće }\end{array}$ & 53 & 10.8 & $\begin{array}{l}\text { For being the } \\
\text { best-quality brand } \\
\text { to je marka } \\
\text { najbolje kvalitete }\end{array}$ & 75 & 15.3 \\
\hline $\begin{array}{l}\text { Because there are } \\
\text { too many ads } \\
\text { ima previše oglasa }\end{array}$ & 38 & 7.7 & $\begin{array}{l}\text { Because there are } \\
\text { too many ads } \\
\text { ima previše oglasa }\end{array}$ & 46 & 9.4 & $\begin{array}{l}\text { Because there are } \\
\text { too many ads } \\
\text { ima previše oglasa }\end{array}$ & 57 & 11.6 \\
\hline $\begin{array}{l}\text { Because the } \\
\text { product is very } \\
\text { affordable } \\
\text { pristupačna je }\end{array}$ & 18 & 3.7 & $\begin{array}{l}\text { Because the } \\
\text { product is very } \\
\text { affordable } \\
\text { pristupačna je }\end{array}$ & 35 & 7.1 & $\begin{array}{l}\text { Because the } \\
\text { product is very } \\
\text { affordable } \\
\text { pristupačna je }\end{array}$ & 45 & 9.2 \\
\hline
\end{tabular}


Table 3 Consumers' favourite brands

Tablica 3. Robne marke koje kupci preferiraju

\begin{tabular}{|c|c|c|c|}
\hline $\begin{array}{c}\text { Rank } \\
\text { Poredak }\end{array}$ & $\begin{array}{c}\text { Brand } \\
\text { Robna marka }\end{array}$ & $\boldsymbol{N}$ & $\begin{array}{c}\text { Percentage } \\
\text { Postotak }\end{array}$ \\
\hline 1 & İstikbal & 196 & 39.9 \\
\hline 2 & Bellona & 94 & 19.1 \\
\hline 3 & Ikea & 45 & 9.2 \\
\hline 4 & Doğtas & 41 & 8.4 \\
\hline 5 & Kelebek & 38 & 7.7 \\
\hline 6 & Yataş Enza Home & 21 & 4.3 \\
\hline 7 & Çilek & 16 & 3.3 \\
\hline 8 & Kilim & 8 & 1.6 \\
\hline 9 & Teleset & 6 & 1.2 \\
\hline 10 & Adore & 6 & 1.2 \\
\hline
\end{tabular}

\begin{tabular}{|c|c|c|c|}
\hline $\begin{array}{c}\text { Rank } \\
\text { Poredak }\end{array}$ & $\begin{array}{c}\text { Brand } \\
\text { Robna marka }\end{array}$ & $\boldsymbol{N}$ & $\begin{array}{c}\text { Percentage } \\
\text { Postotak }\end{array}$ \\
\hline 11 & Tepe Home & 4 & 1 \\
\hline 12 & Yağmur & 3 & 1 \\
\hline 13 & Merinos & 3 & 1 \\
\hline 14 & Alfemo & 2 & 0 \\
\hline 15 & Mondi & 2 & 0 \\
\hline 16 & Gündoğdu & 2 & 0 \\
\hline 17 & İpek & 2 & 0 \\
\hline 18 & Meltem & 1 & 0 \\
\hline 19 & Weltew & 1 & 0 \\
\hline
\end{tabular}

reliability. When these results are analysed, it becomes clear that some values are closer than others. This will be addressed in the conclusion.

Identifying consumers' favourite brands and the variables that affect brand equity requires analysis. For this reason, 491 respondents were asked to indicate their favourite panel furniture brands (see Table 3).

Istikbal was the favourite brand, preferred by 39.9 $\%$ of respondents. Bellona was in second place (19\%), and Ikea took the third position (9.2\%). Despite being a Scandinavian brand, Ikea has a sizeable market share in the Turkish panel furniture market. Statistics for other preferred brands are shown in Table 3.

When consumers' panel furniture purchase experience was tested, it was found that $93.1 \%$ (457) of consumers bought panel furniture (from any brand), while $6.9 \%$ (34) have never purchased panel furniture. Also, not all consumers purchased their favourite brands. According to findings, $84.5 \%$ (415) of con-

sumers did buy their favourite PF brands, while $15.5 \%$ (76) did not.

Table 4 shows that $88.3 \%$ of consumers preferred the İstikbal brand, which they had experienced before. Rates of experience with other brands are also shown in Table 4.

It was also found that $90.8 \%$ (415) of all respondents purchased something from their favourite brand, while $9.2 \%$ (42) did not, even though they purchased other brands.

To examine statistical relationships between consumers' favourite panel furniture brands and their demographics, a chi-square analysis was used: At a significance level of $5 \%$, favourite panel furniture brands related to gender, age, city, marital status, education level and monthly income.

As seen in Table 5, two-sided asymptotic values are significant $(p<0.05)$. Therefore, the null hypotheses $(\mathrm{H} 0)$ related to the criteria were rejected. Hence,

Table 4 Details about consumers' favourite panel furniture brands

Tablica 4. Detalji o preferiranim robnim markama pločastog namještaja

\begin{tabular}{|c|c|c|c|c|c|c|c|c|}
\hline \multicolumn{2}{|c|}{$\begin{array}{c}\text { Favourite panel } \\
\text { furniture brands } \\
\text { Preferirana marka } \\
\text { pločastog namještaja }\end{array}$} & Bellona & İstikbal & Kelebek & Doğtaş & Tepe Home & Alfemo & Ikea \\
\hline \multirow[t]{2}{*}{ Yes } & $N$ & 80 & 173 & 29 & 32 & 1 & 2 & 39 \\
\hline & $\%$ & $85.10 \%$ & $88.30 \%$ & $76.30 \%$ & $78.00 \%$ & $25.00 \%$ & $100.00 \%$ & $86.70 \%$ \\
\hline \multirow[t]{2}{*}{ No } & $N$ & 14 & 23 & 9 & 9 & 3 & 0 & 6 \\
\hline & $\%$ & $14.90 \%$ & $11.70 \%$ & $23.70 \%$ & $22.00 \%$ & $75.00 \%$ & $0.00 \%$ & $13.30 \%$ \\
\hline \multicolumn{2}{|c|}{$\begin{array}{c}\text { Favourite panel } \\
\text { furniture brands } \\
\text { Preferirana marka } \\
\text { pločastog namještaja }\end{array}$} & $\begin{array}{c}\text { Yataş Enza } \\
\text { Home }\end{array}$ & Yağmur & Kilim & Mondi & Gündoğdu & Merinos & İpek \\
\hline \multirow[t]{2}{*}{ Yes } & $N$ & 17 & 2 & 5 & 2 & 2 & 3 & 2 \\
\hline & $\%$ & $81.00 \%$ & $66.70 \%$ & $62.50 \%$ & $100.00 \%$ & $100.00 \%$ & $100.00 \%$ & $100.00 \%$ \\
\hline \multirow[t]{2}{*}{ No } & $N$ & 4 & 1 & 3 & 0 & 0 & 0 & 0 \\
\hline & $\%$ & $19.00 \%$ & $33.30 \%$ & $37.50 \%$ & $0.00 \%$ & $0.00 \%$ & $0.00 \%$ & $0.00 \%$ \\
\hline \multicolumn{2}{|c|}{$\begin{array}{c}\text { Favourite panel } \\
\text { furniture brands } \\
\text { Preferirana marka } \\
\text { pločastog namještaja }\end{array}$} & Teleset & Adore & Çilek & Meltem & Weltew & & $\begin{array}{c}\text { Total } \\
\text { Ukupno }\end{array}$ \\
\hline \multirow[t]{2}{*}{ Yes } & $N$ & 5 & 5 & 14 & 1 & 1 & & 415 \\
\hline & $\%$ & $83.30 \%$ & $83.30 \%$ & $87.50 \%$ & $100.00 \%$ & $100.00 \%$ & & $84.50 \%$ \\
\hline \multirow[t]{2}{*}{ No } & $N$ & 1 & 1 & 2 & 0 & 0 & & 76 \\
\hline & $\%$ & $16.70 \%$ & $16.70 \%$ & $12.50 \%$ & $0.00 \%$ & $0.00 \%$ & & $15.50 \%$ \\
\hline
\end{tabular}


Table 5 Chi-Square analysis and related criteria

Tablica 5. $\chi^{2}$ analiza i srodni kriteriji

\begin{tabular}{|c|c|c|c|c|c|c|}
\hline \multicolumn{2}{|c|}{ Chi-Square tests } & \multicolumn{3}{c|}{ Chi-Square tests } \\
$\chi^{2}$-testovi
\end{tabular}

the relevant criteria influenced the chosen favourite PF brands. They varied depending on the above criteria.

Explanatory factor analysis has been applied to 47 items in the questionnaire. Its findings are as follows:

As seen in Table 6, the calculated KMO value was 0.884 (very good), which means that the data set is suitable for factor analysis. The Bartlett test's significance value shows that the test is significant. With these high correlations, the data set is suitable for factor analysis (see Table 7 below).

Factor analysis of Table 7 shows that 47 items were reduced to 28 and collected in five different factors, including marketing activities, perceived quality, brand awareness, brand association and price (see Table 8 below).

As shown in Table 8, the cumulative contribution of these five factors to the variance is $52.466 \%$. In practice, especially in the social sciences, it is considered sufficient if the variance explained in multi-factorial patterns is between $40 \%$ and $60 \%$ (Çokluk et al., 2012). In this context, contribution of the defined factors to the variance is sufficient.

To reveal the validity of the factors identified in this paper, it is useful to mention the following points: This paper and many others that focus on CBBE, followed Aaker and Keller's models. The summary of the factors in their models is as follows: brand loyalty, brand awareness (recognition and recall), perceived quality, brand associations (image), brand assets, and brand knowledge (Aaker, 1991; Keller, 1993).

In this context, while the factors determined in this paper are consistent with the literature, there also are some differences. First of all, the identified factors are marketing activities, perceived quality, brand awareness, brand association and price. Since, this study was based on Aaker's model, factors affecting
Table 6 KMO and Bartlett's test results

Tablica 6. Rezultati KMO i Bartlettova testa

\begin{tabular}{|c|c|c|}
\hline \multicolumn{3}{|c|}{ KMO and Bartlett's tests } \\
\hline \multicolumn{2}{|c|}{$\begin{array}{l}\text { Kaiser-Meyer-Olkin measure of sampling } \\
\text { adequacy. }\end{array}$} & 0.884 \\
\hline \multirow{3}{*}{$\begin{array}{l}\text { Bartlett's test of } \\
\text { sphericity }\end{array}$} & Approx. Chi-Square & 9.425 .015 \\
\hline & $d f$ & 1081 \\
\hline & Significance & 0 \\
\hline
\end{tabular}

CBBE in the panel furniture industry are mostly consistent with the original model. However, unlike in Aaker's model, marketing activities and price have been identified as two new factors that affect CBBE.

In this paper, brand loyalty and brand assets dimensions of Aaker's model were not identified as important variables. Perhaps this is because Turkish consumers' behaviour is different from the behaviour of other countries' consumers, or because of the structure of the furniture industry, which is extremely large and costlier than many other industries in CBBE studies. In other words, variables arising because of market structure can also help consumers value the brands. On the other hand, 'other proprietary brand assets', in Aaker's brand equity model, is generally used in financial studies rather than in CBBE studies. It is also necessary to keep in mind that some factors, noted above, interact with each other.

As already mentioned, we adopted Yoo and Donthu's (2001) CBBE scale, which is based on that of Aaker and Keller. The principal factors of their scale are effective in creating $\mathrm{CBBE}$ and in keeping factors substantially consistent. The factors (dimensions) in Yoo and Donthu's scale are the perceived quality, brand loyalty, brand awareness, and brand association (Yoo and Donthu, 2001). 
A correlation analysis was performed to determine the relationships between items in factor groups and their significance levels.

In this paper, moderate and high correlation values were taken into account, and related items were examined. Items with low correlation values were not examined. The findings of our analysis are as follows:
The items in Table 9 were listed and abbreviated as follows:

"A." The advertising campaigns for the brand are seen frequently; "B." The brand has effective ads; "C." The brand's slogans are catchy; "D." The brand is constantly reminded to the consumers; "E." The brand goes on sale frequently; "F." More stores sell the brand,

Table 7 Factor analysis final results

Tablica 7. Konačni rezultati faktorske analize

\begin{tabular}{|c|c|c|c|c|c|}
\hline \multicolumn{6}{|l|}{ Rotated Component Matrix ${ }^{a}$} \\
\hline & \multicolumn{5}{|c|}{ Component / Sastavnica } \\
\hline & 1 & 2 & 3 & 4 & 5 \\
\hline $\begin{array}{l}\text { Advertising campaigns for the brand are seen frequently / Često se vide reklamne } \\
\text { kampanje za robnu marku }\end{array}$ & 0.792 & 0.018 & 0.017 & -0.035 & 0.048 \\
\hline The brand has effective ads / Robna marka ima efektne oglase & 0.741 & 0.081 & 0.094 & -0.035 & 0.138 \\
\hline The brand's slogans are catchy / Slogani robne marke su privlačni & 0.732 & 0.094 & 0.177 & -0.008 & 0.081 \\
\hline $\begin{array}{l}\text { The brand is constantly reminded to the consumers / Potrošače se stalno } \\
\text { podsjeća na robnu marku }\end{array}$ & 0.720 & 0.061 & 0.011 & -0.128 & -0.032 \\
\hline $\begin{array}{l}\text { More stores sell the brand, versus competing brands / Robna se marka prodaje } u \\
\text { više trgovina nego konkurentski proizvodi }\end{array}$ & 0.620 & 0.136 & -0.075 & 0.274 & 0.027 \\
\hline The brand goes on sale frequently / Robna je marka često na popustu & 0.614 & -0.047 & 0.083 & 0.009 & -0.186 \\
\hline The brand has high market share / Robna marka ima visok tržišni udio & 0.578 & 0.292 & 0.194 & -0.072 & 0.062 \\
\hline $\begin{array}{l}\text { The brand is distributed through as many stores as possible / Robna se marka } \\
\text { distribuira putem što više trgovina }\end{array}$ & 0.556 & 0.218 & -0.010 & 0.273 & -0.042 \\
\hline $\begin{array}{l}\text { Compared to competing brands, ad campaigns for the brand are more costly } \\
\text { Oglasne su kampanje skuplje od kampanja konkurentskih marki }\end{array}$ & 0.508 & 0.025 & 0.161 & 0.234 & 0.242 \\
\hline The brand has good product variety / Robna marka ima dobru raznolikost & 0.492 & 0.256 & 0.186 & -0.232 & -0.067 \\
\hline $\begin{array}{l}\text { The products are sold in stores that offer well-known brands / Proizvodi se } \\
\text { prodaju u trgovinama s dobro poznatim robnim markama }\end{array}$ & 0.419 & 0.258 & -0.206 & 0.216 & 0.028 \\
\hline The products are priced fairly / Proizvodi imaju poštenu cijenu & 0.135 & 0.742 & 0.071 & -0.139 & 0.009 \\
\hline $\begin{array}{l}\text { Brand quality is likely extremely high / Kvaliteta robne marke vjerojatno je vrlo } \\
\text { visoka }\end{array}$ & 0.096 & 0.738 & 0.104 & 0.019 & -0.008 \\
\hline The brand is high-quality / Robna je marka visoke kvalitete & 0.093 & 0.734 & 0.041 & 0.047 & 0.196 \\
\hline $\begin{array}{l}\text { The likelihood that the brand's new products will be functional is very high } \\
\text { Vrlo je velika vjerojatnost da će novi proizvodi biti funkcionalni }\end{array}$ & 0.081 & 0.677 & 0.134 & -0.138 & 0.036 \\
\hline The brand is priced fairly / Robna marka ima poštenu cijenu & 0.075 & 0.634 & 0.131 & -0.051 & -0.091 \\
\hline $\begin{array}{l}\text { Even if another brand has the same features, I prefer to buy this brand / Čak i ako } \\
\text { druga robna marka ima jednaka obilježja, radije bih kupio/kupila ovu robnu marku }\end{array}$ & 0.071 & 0.497 & 0.358 & 0.000 & -0.067 \\
\hline $\begin{array}{l}\text { The brand uses high technology / Robna se marka proizvodi visokom } \\
\text { tehnologijom }\end{array}$ & 0.212 & 0.471 & 0.237 & -0.099 & 0.143 \\
\hline $\begin{array}{l}\text { It makes sense to buy this brand instead of any other, even if they are essentially } \\
\text { the same / Ima smisla kupiti ovu robnu marku umjesto bilo koje druge, čak } i \text { ako } \\
\text { su jednake }\end{array}$ & 0.084 & 0.462 & 0.243 & 0.226 & 0.003 \\
\hline $\begin{array}{l}\text { I can recognise the brand among other competing brands / Tu robnu marku mogu } \\
\text { prepoznati medu ostalim konkurentskim proizvodima }\end{array}$ & 0.090 & 0.152 & 0.823 & 0.036 & 0.027 \\
\hline I am aware of the brand / Svjestan/svjesna sam robne marke & 0.073 & 0.218 & 0.781 & -0.070 & 0.081 \\
\hline $\begin{array}{l}\text { I have enough knowledge about the brand / Imam dovoljno znanja o toj robnoj } \\
\text { marki }\end{array}$ & 0.152 & 0.201 & 0.744 & 0.011 & -0.032 \\
\hline $\begin{array}{l}\text { Some characteristics of the brand come to my mind quickly / Nekih se obilježja } \\
\text { robne marke odmah sjetim }\end{array}$ & 0.040 & 0.178 & 0.666 & 0.103 & -0.027 \\
\hline $\begin{array}{l}\text { The brand's products seem to be of very poor quality / Proizvodi marke vrlo su } \\
\text { loše kvalitete }\end{array}$ & 0.023 & -0.158 & 0.059 & 0.780 & -0.146 \\
\hline $\begin{array}{l}\text { I have difficulty imagining the brand in my mind / Teško mi je zamisliti robnu } \\
\text { marku }\end{array}$ & 0.054 & 0.047 & -0.051 & 0.737 & 0.094 \\
\hline $\begin{array}{l}\text { The brand is preferable because it is from another country / Robna je marka } \\
\text { poželjnija jer je iz druge zemlje }\end{array}$ & 0.004 & -0.094 & 0.086 & 0.663 & -0.186 \\
\hline The price of the brand is high / Cijena robne marke je visoka & 0.071 & 0.041 & 0.027 & 0.029 & 0.864 \\
\hline The price of the brand is low / Cijena robne marke je niska & -0.016 & -0.048 & 0.014 & 0.369 & -0.752 \\
\hline
\end{tabular}

Extraction Method: Principal Component Analysis. / Metoda ekstrakcije: analiza glavnih komponenata.

Rotation Method: Varimax with Kaiser Normalization. / Metoda rotacije: Varimax s Kaiserovom normalizacijom.

aRotation converged in 6 iterations. / Rotacija je konvergirala u šest ponavljanja. 
Table 8 Total variance explained by factors

Tablica 8. Ukupna varijanca objašnjena uz pomoć faktora

\begin{tabular}{|l|c|c|c|c|c|c|}
\hline \multicolumn{7}{|c|}{ Total variance explained / Objašnjenje ukupne varijance } \\
\hline \multicolumn{3}{|c|}{ Component/Sastavnica } & \multicolumn{3}{|c|}{ Initial eigenvalues } & \multicolumn{3}{c|}{ Rotation sums of squared loadings } \\
\cline { 2 - 8 } & Total $\begin{array}{c}\% \text { of } \\
\text { variance }\end{array}$ & Cumulative \% & Total & $\begin{array}{c}\% \text { of } \\
\text { variance }\end{array}$ & Cumulative \% \\
\hline 1- Marketing activities / marketinške aktivnosti & 6.189 & 22.102 & 22.102 & 4.463 & 15.939 & 15.939 \\
\hline 2- Perceived quality / percipirana kvaliteta & 3.065 & 10.947 & 33.049 & 3.666 & 13.094 & 29.033 \\
\hline 3- Brand awareness / prepoznatljivost marke & 2.340 & 8.356 & 41.406 & 2.790 & 9.965 & 38.998 \\
\hline 4- Brand association / povezanost marke & 1.734 & 6.194 & 47.599 & 2.179 & 7.782 & 46.780 \\
\hline 5- Price / cijena & 1.363 & 4.867 & 52.466 & 1.592 & 5.686 & 52.466 \\
\hline
\end{tabular}

Table 9 Correlation analysis results of items in Factor Group 1

Tablica 9. Rezultati korelacijske analize stavki za grupu 1.

\begin{tabular}{|c|c|c|c|c|c|c|c|c|c|c|c|c|}
\hline & & A & B & $\mathrm{C}$ & $\mathrm{D}$ & E & $\mathrm{F}$ & G & $\mathrm{H}$ & I & $\mathrm{J}$ & $\mathrm{K}$ \\
\hline \multirow{2}{*}{ A } & $\begin{array}{c}\text { Pearson } \\
\text { correlation }\end{array}$ & 1 & $0.505^{* *}$ & $0.523^{* *}$ & $0.605^{* *}$ & $0.436^{* *}$ & $0.433^{* *}$ & $0.424^{* *}$ & $0.330^{* *}$ & $0.429^{* *}$ & $0.320^{* *}$ & \\
\hline & $\begin{array}{l}\text { Significance } \\
\text { (2-tailed) }\end{array}$ & & 0 & 0 & 0 & 0 & 0 & 0 & 0 & 0 & 0 & \\
\hline \multirow{2}{*}{ B } & $\begin{array}{c}\text { Pearson } \\
\text { correlation }\end{array}$ & & 1 & $0.675^{* *}$ & $0.470^{* *}$ & $0.339^{* *}$ & $0.369^{* *}$ & $0.447^{* *}$ & $0.323^{* *}$ & $0.343^{* *}$ & $0.342^{* *}$ & \\
\hline & $\begin{array}{l}\text { Significance } \\
\text { (2-tailed) }\end{array}$ & & & 0 & 0 & 0 & 0 & 0 & 0 & 0 & 0 & \\
\hline \multirow{2}{*}{ C } & $\begin{array}{c}\text { Pearson } \\
\text { correlation }\end{array}$ & & & 1 & $0.429^{* *}$ & $0.347^{* *}$ & $0.389^{* *}$ & $0.446^{* *}$ & $0.356^{* *}$ & $0.337^{* *}$ & $0.383^{* *}$ & \\
\hline & $\begin{array}{c}\text { Significance } \\
\text { (2-tailed) }\end{array}$ & & & & 0 & 0 & 0 & 0 & 0 & 0 & 0 & \\
\hline \multirow{2}{*}{ D } & $\begin{array}{c}\text { Pearson } \\
\text { correlation }\end{array}$ & & & & 1 & $0.387^{* *}$ & $0.343^{* *}$ & $0.359^{* *}$ & & $0.328^{* *}$ & $0.327^{* *}$ & \\
\hline & $\begin{array}{l}\text { Significance } \\
\text { (2-tailed) }\end{array}$ & & & & & 0 & 0 & 0 & & 0 & 0 & \\
\hline \multirow{2}{*}{$\mathrm{E}$} & $\begin{array}{l}\text { Pearson } \\
\text { correlation }\end{array}$ & & & & & 1 & $0.319^{* *}$ & & $0.326^{* *}$ & & & \\
\hline & $\begin{array}{l}\text { Significance } \\
\text { (2-tailed) }\end{array}$ & & & & & & 0 & & 0 & & & \\
\hline \multirow{2}{*}{$\mathrm{F}$} & $\begin{array}{c}\text { Pearson } \\
\text { correlation }\end{array}$ & & & & & & 1 & & $0.508^{* *}$ & $0.306^{* *}$ & & $0.412^{* *}$ \\
\hline & $\begin{array}{c}\text { Significance } \\
\text { (2-tailed) }\end{array}$ & & & & & & & & 0 & 0 & & 0 \\
\hline \multirow{2}{*}{ G } & $\begin{array}{c}\text { Pearson } \\
\text { correlation }\end{array}$ & & & & & & & 1 & $0.314^{* *}$ & & $0.524^{* *}$ & \\
\hline & $\begin{array}{l}\text { Significance } \\
\text { (2-tailed) }\end{array}$ & & & & & & & & 0 & & 0 & \\
\hline \multirow{2}{*}{$\mathrm{H}$} & $\begin{array}{c}\text { Pearson } \\
\text { correlation }\end{array}$ & & & & & & & & 1 & & & $0.375^{* *}$ \\
\hline & $\begin{array}{l}\text { Significance } \\
\text { (2-tailed) }\end{array}$ & & & & & & & & & & & 0 \\
\hline
\end{tabular}

**Correlation is significant at the 0.01 level (2-tailed). / **Korelacija je značajna na razini 0,01 (dvostrana).

*Correlation is significant at the 0.05 level (2-tailed). / *Korelacija je značajna na razini 0,05 (dvostrana).

versus competing brands; "G." The brand has high market share; "H." The brand is distributed through as many stores as possible; "I." Compared to competing brands, ad campaigns for the brand are more costly; "J." The brand has good product variety; "K." The brand's products are sold in stores that offer wellknown brands.

Examining the data in Table 9, correlation values of items in marketing activities provided the following findings. The brand has effective ads and The brand's slogans are catchy had the strongest correlation value $\left(.675^{* *}\right)$ in this factor set. Therefore, a partly high positive correlation is seen in these items. On the other hand, The advertising campaigns for the brand are frequently seen and The brand is constantly reminded to the consumers items showed a moderately positive correlation $\left(.605^{* *}\right)$, the second-strongest value in this factor set. Finally, The brand has high market share and The brand has good product variety showed a moderately positive $(.524 * *)$ correlation, the thirdstrongest value in this factor set. Table 9 shows other moderate and high correlation values. 
Table 10 Correlation analysis results of items in Factor Group 2

Tablica 10. Rezultati korelacijske analize stavki za grupu 2.

\begin{tabular}{|c|c|c|c|c|c|c|c|c|c|}
\hline & & $\mathrm{L}$ & $\mathrm{M}$ & $\mathrm{N}$ & $\mathrm{O}$ & $\mathrm{P}$ & $\mathrm{R}$ & $\mathrm{S}$ & $\mathrm{T}$ \\
\hline \multirow{2}{*}{$\mathrm{L}$} & Pearson correlation & 1 & $0.500^{* *}$ & $0.446^{* *}$ & $0.441^{* *}$ & $0.450^{* *}$ & $0.333^{* *}$ & $0.414^{* *}$ & $0.316^{* *}$ \\
\hline & Sig. (2-tailed) & & 0 & 0 & 0 & 0 & 0 & 0 & 0 \\
\hline \multirow{2}{*}{ M } & Pearson correlation & & 1 & $0.508^{* *}$ & $0.521^{* *}$ & $0.385^{* *}$ & $0.307^{* *}$ & $0.359^{* *}$ & \\
\hline & Significance (2-tailed) & & & 0 & 0 & 0 & 0 & 0 & \\
\hline \multirow{2}{*}{$\mathrm{N}$} & Pearson correlation & & & 1 & $0.462^{* *}$ & $0.397^{* *}$ & $0.312^{* *}$ & $0.365^{* *}$ & \\
\hline & Significance (2-tailed) & & & & 0 & 0 & 0 & 0 & \\
\hline \multirow{2}{*}{$\mathrm{O}$} & Pearson correlation & & & & 1 & $0.378^{* *}$ & $0.337^{* *}$ & $0.362^{* * *}$ & \\
\hline & Significance (2-tailed) & & & & & 0 & 0 & 0 & \\
\hline \multirow{2}{*}{$\mathrm{R}$} & Pearson correlation & & & & & & 1 & & $0.382^{* *}$ \\
\hline & Significance (2-tailed) & & & & & & & & 0 \\
\hline
\end{tabular}

**Correlation is significant at the 0.01 level (2-tailed). / **Korelacija je značajna na razini 0,01 (dvostrana).

*Correlation is significant at the 0.05 level (2-tailed). / Korelacija je značajna na razini 0,05 (dvostrana).

Items in Table 10 were listed and abbreviated as $\mathrm{L}, \mathrm{M}, \mathrm{N}, \mathrm{O}, \mathrm{P}, \mathrm{R}, \mathrm{S}$ and $\mathrm{T}$.

"L." The products are priced fairly; "M." Brand quality is likely extremely high; "N." The brand is of high quality; "O." The likelihood that the brand's new products will be functional is very high; "P." The brand is priced fairly; "R." Even if another brand had the same features, I prefer to buy this brand; "S." The brand uses high technology; "T." It makes sense to buy this brand instead of any other brand, even if they are essentially the same.

Examining the data in Table 10, the correlation value of Brand quality is likely extremely high and The likelihood that the brand's new products will be functional is very high provided the strongest value $\left(.521^{* *}\right)$ in this factor set. Accordingly, there is a moderately positive correlation between these items. Brand quality is likely extremely high and The brand is of high quality give a moderately positive correlation $\left(.508^{* *}\right)$, the second-highest in this factor set. Finally, The brand is priced fairly and The likelihood that the brand's new products will be functional is very high gives a moderately positive $\left(.500^{* *}\right)$ correlation, the third-strongest value in this factor set. Other correlation values are shown in Table 10.

The items in Table 11 were listed and abbreviated as $\mathrm{U}, \mathrm{V}, \mathrm{Y}$ and $\mathrm{Z}$.

"U." I can recognise the brand among other competing brands; "V." I am aware of the brand; "Y." I have enough knowledge about the brand; "Z." Some characteristics of the brand come to my mind quickly.

Table 11 Correlation analysis results of items in Factor Group 3

Tablica 11. Rezultati korelacijske analize stavki za grupu 3.

\begin{tabular}{|c|c|c|c|c|c|}
\hline & $\mathrm{U}$ & $\mathrm{V}$ & $\mathrm{Y}$ & $\mathrm{Z}$ \\
\hline \multirow[t]{2}{*}{$\mathrm{U}$} & Pearson correlation & 1 & $0.704^{* *}$ & $0.554^{* *}$ & $0.425^{* *}$ \\
\hline & Significance (2-tailed) & & 0 & 0 & 0 \\
\hline \multirow[t]{2}{*}{ V } & Pearson correlation & & 1 & $0.504^{* *}$ & $0.414^{* *}$ \\
\hline & Significance (2-tailed) & & & 0 & 0 \\
\hline \multirow[t]{2}{*}{ Y } & Pearson correlation & & & 1 & $0.517^{* *}$ \\
\hline & Significance (2-tailed) & & & & 0 \\
\hline
\end{tabular}

Examining the data in Table 11, the correlation value of the statements $I$ can recognise the brand among other competing brands and I am aware of brand items have the strongest value $\left(.704^{* *}\right)$ in this factor set. On the other hand, the statements I can recognise the brand among other competing brands and I have enough knowledge about the brand items have a moderately positive correlation $\left(.554^{* *}\right)$, the secondstrongest value in this factor set. Finally, I have enough knowledge of the brand and Some characteristics of the brand come to my mind quickly have a moderately positive $\left(.517^{* *}\right)$ correlation, the third-strongest value in this factor set. Only the three strongest correlation values are mentioned here.

The items in Table 12 were listed and abbreviated as $\mathrm{W}, \mathrm{Q}$ and $\mathrm{X}$.

"W." The brand's products seem to be of very poor quality; "Q." I have difficulty imagining the brand in my mind; "X." The brand is preferable because it is from another country.

Examining the data in Table 12, the correlation value of The brand's products seem to be of very poor quality and I have difficulty imagining the brand in my mind showed the strongest value $\left(.473^{* *}\right)$ in this factor set. There was a moderately positive correlation between these items. On the other hand, The brand's products seem to be of very poor quality and The brand is preferable because it is from another country had a moderately positive correlation (.468**), the secondstrongest value in this factor set. Finally, the statements I have difficulty imagining the brand in my mind and

Table 12 Correlation analysis results of items in Factor Group 4

Tablica 12. Rezultati korelacijske analize stavki za grupu 4.

\begin{tabular}{|c|l|c|c|c|}
\hline \multicolumn{2}{|c|}{} & W & Q & X \\
\hline \multirow{2}{*}{ W } & Pearson correlation & 1 & $0.473^{* *}$ & $0.468^{* *}$ \\
\cline { 2 - 5 } & Significant (2-tailed) & & 0 & 0 \\
\hline \multirow{2}{*}{ Q } & Pearson correlation & & 1 & $0.309^{* *}$ \\
\cline { 2 - 5 } & Significant ( (2-tailed) & & & 0 \\
\hline
\end{tabular}

**Correlation is significant at the 0.01 level (2-tailed).

**Korelacija je značajna na razini 0,01 (dvostrana).

*Correlation is significant at the 0.05 level (2-tailed)

* Korelacija je značajna na razini 0,05 (dvostrana). 
Table 13 Correlation analysis results of items in Factor Group 5

Tablica 13. Rezultati korelacijske analize stavki za grupu 5.

\begin{tabular}{|c|l|c|c|}
\hline \multicolumn{2}{|c|}{ A1 } & A1 & A2 \\
\cline { 2 - 4 } & Significance (2-tailed) & 1 & $-0.487^{* *}$ \\
\hline
\end{tabular}

**Correlation is significant at the 0.01 level (2-tailed).

**Korelacija je značajna na razini 0,01 (dvostrana).

*Correlation is significant at the 0.05 level (2-tailed).

*Korelacija je značajna na razini 0,05 (dvostrana).

The brand is preferable because it is from another country showed a moderately positive $(.309 * *)$ correlation, the third-strongest value in this factor set.

The items in Table 13 were listed and abbreviated as A1 and A2.

"A1." The price of the brand is high; "A2." The price of the brand is low.

Examining the data in Table 13, the correlation value of The price of the brand is high and The price of the brand is low was $\left(-.487^{* *}\right)$, suggesting a moderately negative correlation between these items.

The foregoing correlation analysis placed items in different categories, with largely low and moderate correlations being found. However, as a result of the performed correlation analysis, a special case has been identified: the existence of moderate interactions was observed between some of the items from different categories. For a better explanation, see Table 14.

Items and factor groups examined by correlation analysis can be summarised as follows:

Eleven items about marketing activities were made:

1. Ad campaigns for the brand are seen frequently.

2. The brand has effective ads.

3. The brand's slogans are catchy.

4. The brand is constantly reminded to the consumers.

5. More stores sell the brand, versus competing brands.

6. The brand goes on sale frequently

7. The brand has high market share.

8. The brand is distributed through as many stores as possible.

9. Compared to competing brands, ad campaigns for the brand are more costly.

10. The brand has good product variety.

11. The brand's products are sold in stores that offer well-known brands.
Eight items about perceived quality were made:

1. The products are priced fairly.

2. The brand quality is likely extremely high.

3. The brand is of high quality.

4. The likelihood that the brand's new products will be functional is very high.

5. The brand is priced fairly.

6. Even if another brand has the same features, I prefer to buy this brand.

7. The brand uses high technology.

8. It makes sense to buy this brand instead of any other, even if they are essentially the same.

There were four brand awareness items:

1. I can recognise the brand among other competing brands.

2. I am aware of the brand.

3. I have enough knowledge about the brand.

4. Some characteristics of the brand come to my mind quickly.

There were three brand association items:

1. The brand's products seem to be of very poor quality.

2. I have difficulty imagining the brand in my mind.

3 . It is preferable because it is from another country.

Finally, the two price-factor items were:

1. The price of the brand is high.

2. The price of the brand is low.

As can be seen from the correlation analysis, items in the same factor group directly affect each other. As in Yoo and Donthu (2001)'s original scale, items are clustered by similar factors. Therefore, the determining factors of the developed scale and the items in the factor groups are consistent with the literature.

\section{CONCLUSIONS}

4. ZAKLJUČAK

According to the consumer demographics, the categorical distribution of 491 people in this research was found balanced.

In the beginning of the survey, respondents were asked some questions. All of them (100\%) were able to recall at least one brand. However, the number of consumers was decreasing, while the number of recalled brands was increasing. Most respondents were able to recall a maximum of three brands. In addition, the three most preferred brands were the same as the three brands recalled by the consumers.

Table 14 Correlation values of items from different factor groups

Tablica 14. Vrijednosti korelacije stavki iz različitih grupa

\begin{tabular}{|c|c|c|c|c|}
\hline & & $\begin{array}{l}\text { I can recognise the brand } \\
\text { among other competing } \\
\text { brands / Tu robnu marku } \\
\text { mogu prepoznati medu } \\
\text { konkurentskim proizvodima }\end{array}$ & $\begin{array}{l}\text { I am aware of } \\
\text { the brand } \\
\text { Svjestan/ } \\
\text { svjesna sam } \\
\text { robne marke }\end{array}$ & $\begin{array}{l}\text { I have enough } \\
\text { knowledge about } \\
\text { the brand / Imam } \\
\text { dovoljno znanja o } \\
\text { toj robnoj marki }\end{array}$ \\
\hline \multirow{2}{*}{$\begin{array}{l}\text { Even if another brand had the same } \\
\text { features, I prefer to buy this brand /čak i ako } \\
\text { druga robna marka ima jednaka obilježja, } \\
\text { radije bih kupio/kupila ovu robnu marku }\end{array}$} & $\begin{array}{l}\text { Pearson } \\
\text { correlation }\end{array}$ & $0.320^{* *}$ & $0.351^{* *}$ & $0.316^{* *}$ \\
\hline & $\begin{array}{l}\text { Significance } \\
\text { (2-tailed) }\end{array}$ & 0 & 0 & 0 \\
\hline
\end{tabular}

**Correlation is significant at the 0.01 level (2-tailed). / **Korelacija je značajna na razini 0,01 (dvostrana).

*Correlation is significant at the 0.05 level (2-tailed). / *Korelacija je značajna na razini 0,05 (dvostrana). 
When consumers were asked to rank brands, they preferred the brands that they had tried in the past. The quality, distribution and attainability of the brand were also very important. Consumers want to reach the products of the brands in the market. Another important reason was brand credibility.

When consumers were asked to define their favourite panel furniture brands, the results were as follows:

- They preferred domestic brands over foreign brands.

- The reasons why consumers preferred certain panel furniture brands were largely the same as why consumers preferred brands in general.

According to the chi-square analysis, the favourite panel furniture brand related to gender, age, city, marital status, education level and monthly income. Other demographics had no effect on the choice of favourite panel furniture brands.

Respondents were asked to give brands personality traits. While positive attributes such as modernity, a pioneering nature, and assertiveness were associated with consumers' favourite brands, attributes such as imitative, passive, unstable and untested were associated with the least-favourite brands.

Overall, 47 items were reduced to 28 , and they were collected in five different factor groups: 'marketing activities', 'perceived quality', 'brand awareness', 'brand association', and 'price'. To examine the relationship between items in the factor groups, correlation analyses were performed, which found that most items in a factor group are interrelated and trigger each other.

If any firm wants to create or strengthen CBBE, they should consider the major factors and criteria defined in this paper one by one. For doing so, items under the relevant factors should be taken into account. In this manner, firms can save time and money by creating CBBE strategy.

Some respondents' brand-equity views, not directly examined in this paper, can shed light on future research. Even though they define the brands they have enjoyed in the past as valuable, most consumers are very open to change. Also, unlike in the literature, consumers' previous brand loyalty was found to be unimportant. This may have been caused by the structure of the panel furniture sector (as mentioned earlier), or it may have been due to the purchasing habits of Turkish consumers. This can be an important starting point, especially for future studies.

Brands' contribution to social responsibility projects is very important for consumers. However, consumers frequently do not have any information about this issue. Therefore, if brands contribute to socially responsibility projects, it is very important for enterprises to emphasise this point when creating brand awareness and brand perception.

Brands that stand behind their products and investigate consumer satisfaction after the sale make consumers feel important. These companies are seen as trustworthy, which creates positive brand perception. To improve a brand's general perception, we recommend that large companies set up call centres. In our survey, an important criticism was that companies do not value consumers after they make purchases.

Finally, according to respondents, brands should be represented by a dealer in every region. Although consumers respond to advertisements, they stated that it is also important to see products physically, which might cause them to make a different purchase decision. Therefore, enterprises looking to create CBBE should pay particular attention to distribution networks and point-of-sale marketing efforts.

\section{REFERENCES}

\section{LITERATURA}

1. Aaker, D. A., 1991: Managing Brand Equity. New York: The Free Press.

2. Baalbaki, S.; Guzmán, F., 2016: A consumer-perceived consumer-based brand equity scale. Journal of Brand Management, 23: 229-251. https://doi.org/10.1057/bm.2016.11.

3. Büyüköztürk, Ş., 2014: Sosyal Bilimler İçin Veri Analizi El Kitab1, 19. Bask1, Pegem Akademi, Ankara.

4. Can, A., 2014: SPSS ile Bilimsel Araştırma Sürecinde Nicel Veri Analizi, 2. Bask1, Pegem Akademi, Ankara.

5. Cobb-Walgren, C. J.; Ruble, C. A.; Donthu, N., 1995: Brand Equity, Brand Preference, and Purchase Intent. Journal of Advertising, 24: 25-40.

6. Colicev, A.; Malshe, A.; Pauwels, K., 2018: Social Media and Customer-Based Brand Equity: An Empirical Investigation in Retail Industry. Administrative Sciences, 8(3): 1-16. https://doi.org/10.3390/admsci8030055.

7. Crimmins, J. C., 1992: Better measurement and management of brand value. Journal of Advertising Research, 32(4): 11-19.

8. Çokluk, Ö.; Şekercioğlu, G.; Büyüköztürk, Ş., 2012: Sosyal Bilimler İçin Çok Değişkenli İstatistik SPSS ve Lisrel Uygulamaları, 2. Bask1, Pegem Akademi, Ankara.

9. Daniel, W. W., 1999: Biostatistics A Foundation for Analysis in the Health Sciences, sixth edition. Hoboken, John Wiley \& Sons, Inc.

10. Datta, H.; Ailawadi, K. L.; van Heerde, H. J., 2017: How Well Does Consumer-Based Brand Equity Align with Sales-Based Brand Equity and Marketing-Mix Response? Journal of Marketing 81: 1-20. https://doi.org/10.1509/jm.15.03.

11. Erdem, T.; Swait, J.; Broniarczyk, S.; Chakravarti, D.; Kapferer, J.-N.; Keane, M.; Roberts, J.; Steenkamp, J. E. M.; Zettelmeyer, F., 1999: Brand Equity, Consumer Learning and Choice. Marketing Letters 10: 301-318.

12. Farquhar, P. H., 1989: Managing Brand Equity, Marketing Research, 1 (September), 24-33.

13. Girard, T.; Trapp, P.; Pinar, M.; Gulsoy, T.; Boyt, T. E., 2017: Consumer-Based Brand Equity of a Private-Label Brand: Measuring and Examining Determinants. Journal of Marketing Theory and Practice, 25: 39-56. https://doi.org/10.1080/10696679.2016.1236662.

14. Hair, J. F.; Black, W. C.; Babin, B. J.; Anderson, R. E.; 2014: Multivariate data analysis, Pearson.

15. Ioannou, M.; Rusu, O., 2012: Consumer-Based Brand Equity: A Cross-Cultural Perspective. Journal of Promotion Management, 18: 344-360.

https://doi.org/10.1080/10496491.2012.696462.

16. Kalaycı, Ş., 2009: SPSS Uygulamalı Çok Değişkenli İstatistik Teknikleri, 4. Bask1, Asil Yayın Dağıtım, Ankara. 
17. Keller, K. L., 1993: Conceptualizing, measuring, and managing customer-based brand equity. Journal of Marketing, 57 (1): 1-22.

18. Keller, K. L., 1998: Strategic Brand Management: Building, Measuring, and Managing Brand Equity. Upper Saddle River, NJ: Prentice Hall.

19. Koçak, A.; Abimbola, T.; Özer, A., 2007: Consumer Brand Equity in a Cross-cultural Replication: An Evaluation of a Scale. Journal of Marketing Management, 23: 157-173. https://doi.org/10.1362/026725707X178611.

20. Lassar, W.; Mittal, B.; Sharma, A., 1995: Measuring customer based brand equity. Journal of Consumer Marketing, 12: 11-19. https://doi.org/10.1108/07363769510095270.

21. McQueen, J., 1991: Leveraging the Power of Emotion in Building Brand Equity, ARF Third Annual Advertising and Promotion Workshop, February 5-6.

22. Netemeyer, R. G.; Krishnan, B.; Pullig, C.; Wang, G.; Yagci, M.; Dean, D.; Ricks, J.; Wirth, F.; 2004: Developing and validating measures of facets of customer-based brand equity. Journal of Business Research, 57: 209-224. https://doi.org/10.1016/S0148-2963(01)00303-4.

23. Pappu, R.; Quester, P. G.; Cooksey, R. W., 2005: Consumer based brand equity: improving the measurement - empirical evidence. Journal of Product and Brand Management, 14: 143-154.

https://doi.org/10.1108/10610420510601012.
24. Swimberghe, K.; Darrat, M. A.; Beal, B. D.; Astakhova, M., 2018: Examining a psychological sense of brand community in elderly consumers. Journal of Business Research, 82: 171-178.

https://doi.org/10.1016/j.jbusres.2017.09.035.

25. Turkstat, 2011: Population And Housing Census, Number of Households by Household Size, Turkish Statistical Institute, Ankara, viewed 15 September 2016. http://www.turkstat.gov.tr/HbGetir.do?id=15843\&tb_id=2.

26. Yoo, B.; Donthu, N., 2001: Developing and validating a multidimensional consumer-based brand equity scale. Journal of Business Research, 52: 1-14.

https://doi.org/10.1016/S0148-2963(99)00098-3.

\section{Corresponding address:}

\section{ILKER AKYUZ, Ph.D.}

Karadeniz Technical University

Faculty of Forestry

TURKEY

e-mail: iakyuz@ktu.edu.tr 